\title{
Laboratory Experiment and Simulation of High-temperature Fluidized Bed Air Receiver for Concentrated Solar Power Generation
}

\author{
Koji Matsubara*1, Yuki KaZuma*1, Atsushi SaKurai*1, Tatsuya KodAmA*1, Nobuyuki GoKon*1, \\ Hyun-Seok CHO ${ }^{* 1}$, Kazuo YoshidA ${ }^{*}{ }^{* 2}$, and Yoshinori NAGASE $* 3$
}

(Received October 30, 2014)

\begin{abstract}
This study proposes a two-tower type fluidized receiver for receiving concentrated solar light at high temperatures is proposed. This fluidized receiver is coupled with the Miyazaki beam-down reflector system. The visualization and the numerical simulation was made for the laboratory model to show the fluid-dynamics and the heat transport as well as to elaborate the existing demonstration model. The experimental visualization of the cold model demonstrated that in each tower, the particles are moved by the aerated organized flow. The numerical simulation was made using the thermal input cited from the $5.0 \mathrm{kWth}$ sun simulator. The numerical simulation demonstrated that the inner particles are heated above $950{ }^{\circ} \mathrm{C}$ after 3.0 minutes of the aeration start time. The increase in temperature is caused by the intrusion of the heated particles from the high-pressure side tower to the low-pressure side tower. It is thus suggested that collective circulation occurs between high- and low-pressure side towers and this can be utilized for a direct thermal storage system.
\end{abstract}

本論文では, 太陽熱発電用の高温度集熱のための二塔流動層式ソーラーレシーバについて検討を行なった。このソーラーレシー バは宮崎大学のビームダウン集光装置と組み合わせる予定である。今回は, 実証試験用ソーラーレシーバを設計するため, コールド モデルによる可視化と数值解析によって内部の現象について検討した。可視化によって, それぞれの流動層内に気泡が発生するこ とを確認できた。数值シミュレーションは, $5 \mathrm{kWth}$ 太陽シミュレー夕に扔ける熱流束分布を条件として使用した。それによって, 集光 照射開始から 3 秒後に粒子温度は 950 度を超えること, および流動層内部の粒子の組織的循環によって熱拡散が促進されること を確認した。以上の検討を通して二塔流動層式ソーラーレシーバの熱流動特性を把握できた。

Key Words

Renewable energy, Solar energy, Fluidized receiver, High temperature, Beam-down reflector

\section{Introduction}

In the light of a growing concern about global warming, research and development of the renewable energy technology is increasing its importance in reducing the carbon dioxide emission level. Solar heat is inexhaustible, clean and ubiquitous energy. It is superior to other natural energy in regards to its ability to be stored either as sensible or latent enthalpy. Recently, concentrating solar

※1 Niigata University

8050, Ikarashi 2-no-cho, Nishi-ku, Niigata-shi, Niigata 950-2181, Japan

※2 Institute of Applied Energy

Shimbashi SY Building, 1-14-2, Nishi-Shimbashi 1-Chome, Minato-ku, Tokyo 105-0003, Japan

※3 University of Miyazaki

1-1, Gakuen Kibanadai-nishi, Miyazaki-shi, Miyazaki 889-2192, Japan power (CSP) plants has been thriving in Europe and in the United States. And new CSP plant constructions are being planned in the sun-belt of Asia as well.

The newest CSP plant adopts the tower type reflector system. In this system, solar ray is concentrated by the heliostat mirrors to the tower top. The concentrated solar light then heats the molten nitrate salt to be transported into a heat storage tank. Using this heat, superheated steam is produced to generate power by a turbine engine. Currently, the temperature of the concentrated heat in such system is around $560^{\circ} \mathrm{C}^{1{ }^{1}}$ ). It is desirable for the solar concentration temperature to be increased to $900^{\circ} \mathrm{C}$ or higher to further improve the thermal efficiency of a CSP

This study was partly presented in the GRE2014. 


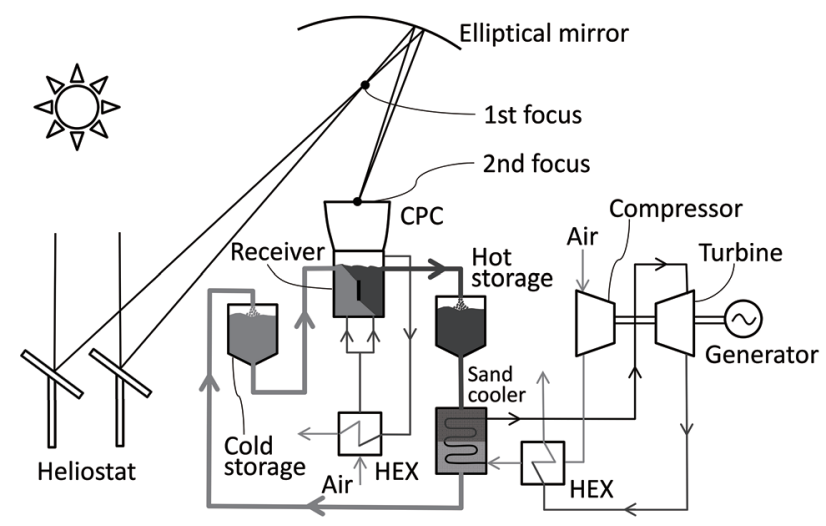

Fig. 1 Solar hot air turbine with fluidized receiver

plant equipped with a solar turbine.

This study focuses on the characteristic analysis of thermal concentration by a fluidized bed air receiver used for concentrated solar radiation. At the University of Miyazaki, a new type of solar receiver is under consideration to be used in combination with the beamdown solar reflector system as shown in Fig. 1. Using the flows of the particles as thermal media for heat concentration and storage, this system is designed to transport sensible enthalpy from concentrated solar light to the heat storage tanks. The stream of hot particles enters the heat exchanger to heat the compressed air. The hot air thus produced works the turbine to generate electricity.

Before conducting the field test, a visualization device was made for the cold model of the two-tower type fluidized receiver. The flow fields of the fluidized particles are numerically computed by a granular model. The velocity vectors of solid particles are discussed below to reveal the flow structures and heat transport mechanisms.

\section{Concept of fluidized receiver}

This paper proposes a two-tower type fluidized receiver illustrated in Fig. 2. The Concept of the fluidized receiver comes from the fluidized reactor by Kodama and Gokon ${ }^{3)}$ and Gokon et al. ${ }^{4)}$.

The existing receivers use the solid surface of tubes or honeycombs to transform concentrated solar light into sensible enthalpy. There are heat-resistant alloy and ceramic materials applied on the receiver surfaces where the temperature are the highest. The thermal concentration temperature is as high as $560^{\circ} \mathrm{C}$ at the solar steam turbine, and around $800^{\circ} \mathrm{C}$ at the hot air turbine in the recent tests. The thermal concentration temperature is restricted by the heat resistance temperature of the materials.

The fluidized receiver applies ceramic particles or quartz sand as thermal concentrating materials. These two are chosen due to their high melting point (e.g. quartz sand

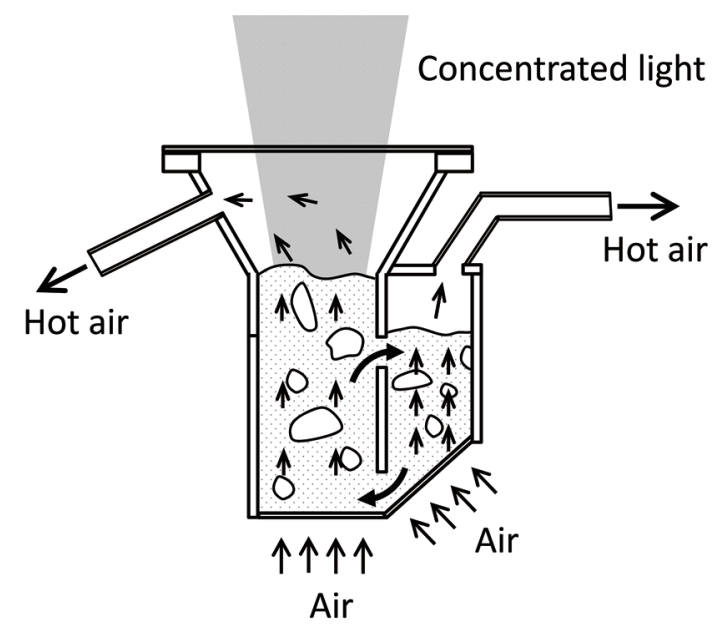

Fig. 2 Schematic two-tower type fluidized receiver

$=1650^{\circ} \mathrm{C}$ ). The use of particles are advantageous due to their resistance to a thermal shock by their fluidity. The particles are also advantageous in transportability so that the particle flow can convey the enthalpy by their mass transport. Therefore, these particles are suitable to be used as receiver materials as well as heat storage materials. A plant concept for a direct heat storage system using the same particles for the thermal concentration and the storage is as already presented in Fig. 1.

Although the particle system can be applied to both the receiver and the heat storage system as described above, this paper focuses on its function in the receiver. The two-tower type fluidized receiver was designed, and its effectiveness was examined. As shown in Fig. 2, the twotower type receiver has a high-pressure side tower (left) and a low-pressure side tower (right), separated by a vertical plate. Both towers has a distributor plate at the bottom through which pressurized air is supplied. The pressure difference results in the velocity difference between the two towers to induce an inner circulation of the particles, causing the exchange of the particles between the towers. Such inner circulation is expected to convey sensible enthalpy through the receiver material to enhance the receiver efficiency.

\section{Experimental visualization}

The particle temperature in a receiver is expected to reach as high as $800^{\circ} \mathrm{C}$ or higher to provide hot air for the gas turbine system. The increase in the temperature causes the fluid to expand, resulting in the flow acceleration and the higher heat transfer rate between fluid and particles. The temperature increase is thus important in analyzing the fluid mechanics of a fluidized receiver. However, there is some challenges in accessing the fluid dynamics of the hot fluidized receiver due to the restriction of the experimental 
apparatus. For this study, a room temperature model of the fluidized receiver is visualized to reveal its fluid mechanics. The experiment was conducted without the use of solar irradiation. This cold apparatus cannot reveal temperature effects, but suitable for the first trial of visualization since it is safe and has low cost.

Fig. 3 shows a transparent channel of the cold model for a two-tower type fluidized receiver. The two-tower type receiver consists of a high pressure tower (left) and a low pressure tower (right). The two towers are linked by slits just above and below the vertical plate. The towers have porous distributor plates at the bottom. The distributor of the low-pressure side tower is set inclined to induce the particle flow from the low- to the high-pressure side towers. The air flow is provided through the distributor plates for the aeration of the particle bed. The high-pressure side tower has a cross-section of $60 \mathrm{~mm}$ sides square. The low-pressure side tower has a cross section of $40 \mathrm{~mm}$ sides square. Their height is $140 \mathrm{~mm}$. A cone at the top of the high- pressure side tower is equipped to take the concentrated light directly to the particle bed surface for the case of experiment with irradiation. The experiments were made using polystyrene beads, $1.04 \mathrm{~g} / \mathrm{cm}^{3}$ in density and $0.7 \mathrm{~mm}$ to $1.4 \mathrm{~mm}$ in diameter

Fig. 4 shows the photographs of the visualization device where the line velocity at the high pressure side is $0.32 \mathrm{~m} / \mathrm{s}$ and that at the low pressure side is $0.31 \mathrm{~m} / \mathrm{s}$. Initially, the white and blue particles form horizontal layers for a clear observation (Fig. 4 (a)). The photographs indicate that the particle layers in two towers are mixed by the aeration. The particle bed in the high pressure side is lifted higher than that of the low pressure side. The difference in bed heights can cause the particle exchange between two towers as shown by the numerical simulation in below.

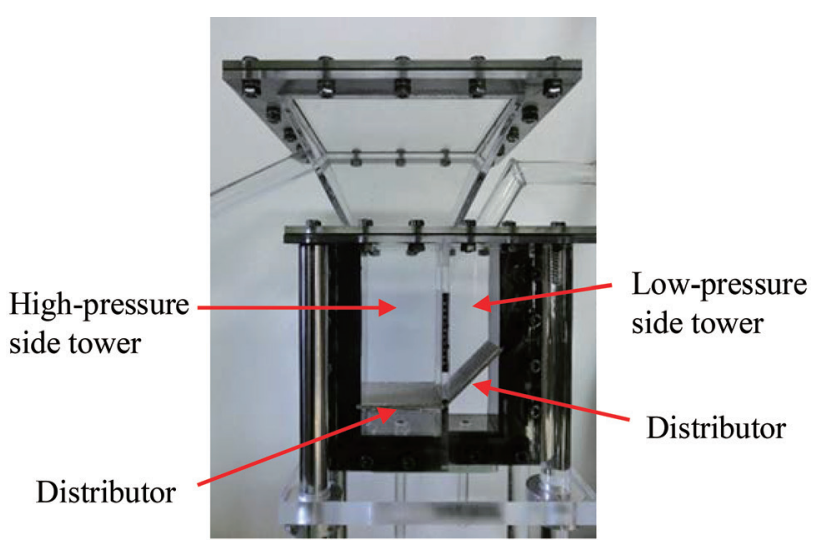

Fig. 3 Transparent channel for visualization of two-tower fluidized bed

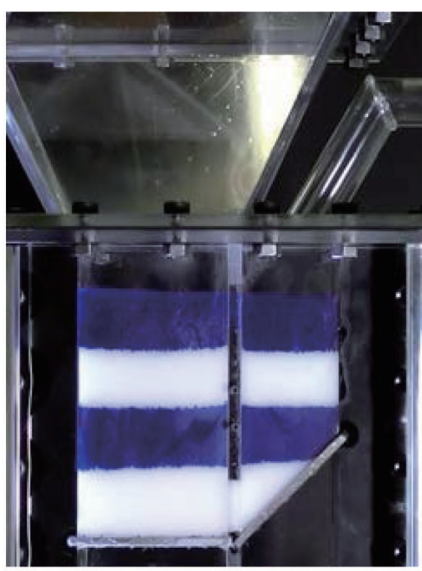

(a) $\mathrm{t}=1[\mathrm{sec}]$

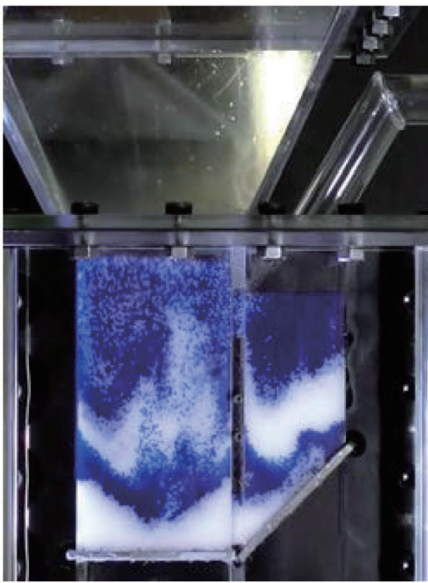

(b) $\mathrm{t}=3[\mathrm{sec}]$

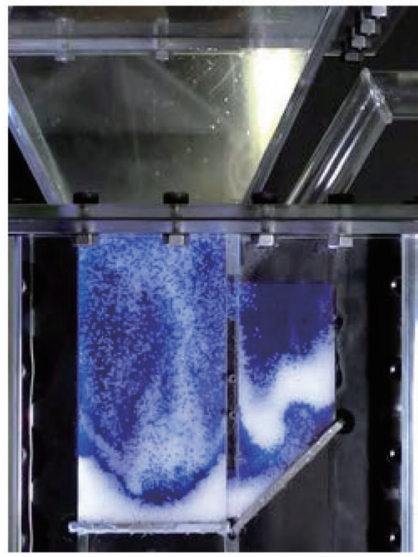

(c) $\mathrm{t}=8[\mathrm{sec}]$

Fig. 4 Visualization of cold model

\section{Numerical simulation}

For this paper, the numerical simulation of two tower type fluidized receiver is performed to examine the irradiation of concentrated solar light. The change in density caused by temperature fluctuation is taken into account to reveal fluid dynamics affected by high temperature. Fig. 5 shows the computational domain for numerical simulation of the fluidized receiver. The two-dimensional simulation was 
performed to reduce the computational load.

The distribution of the radiation flux is obtained from the experiment of $5.0 \mathrm{kWth}$ sun simulator shown in Fig. 6. The two-dimensional distribution of radiation flux is measured by the Gardon gauge as shown in Fig. $7^{4)}$. The peak of flux is above $4000 \mathrm{~kW} / \mathrm{m}^{2}$. The radiation is averaged line by line to yield the two-dimensional distribution as shown in Fig. 8. It indicates that the heat flux is $2000 \mathrm{~kW} / \mathrm{m}^{2}$ at the highest. The mean value is as high as $1000 \mathrm{~kW} / \mathrm{m}^{2}$, which is comparable to the current solar power generation. The simulation treats the two-dimensional model which has the same geometry as the visualized model. The simulation assumes the ceramic particles with the density of $6.87 \mathrm{~g} / \mathrm{cm}^{3}$, the specific heat of $456 \mathrm{~J} / \mathrm{kg} \cdot \mathrm{K}$, and the thermal conductivity of $0.76 \mathrm{~W} / \mathrm{m} \cdot \mathrm{K}$. The particle diameter is set at $450 \mu \mathrm{m}$. The larger particles were selected in the experimental visualization for better visibility. The numerical simulation treats the smaller particles which are

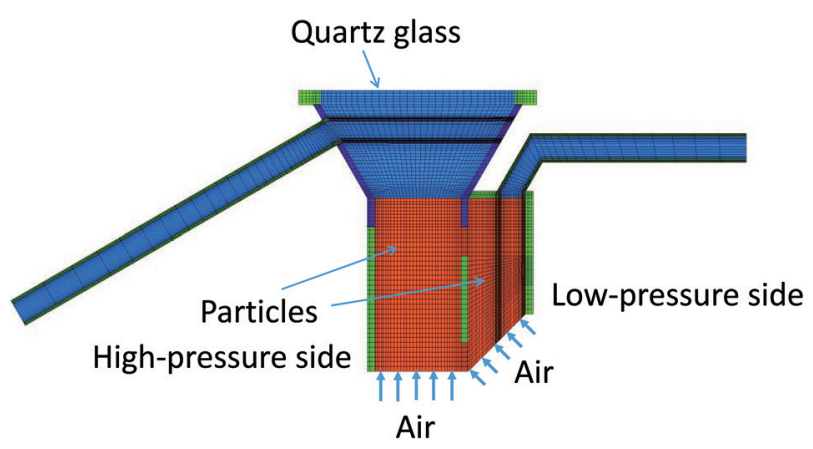

Fig. 5 Two-tower type fluidized receiver

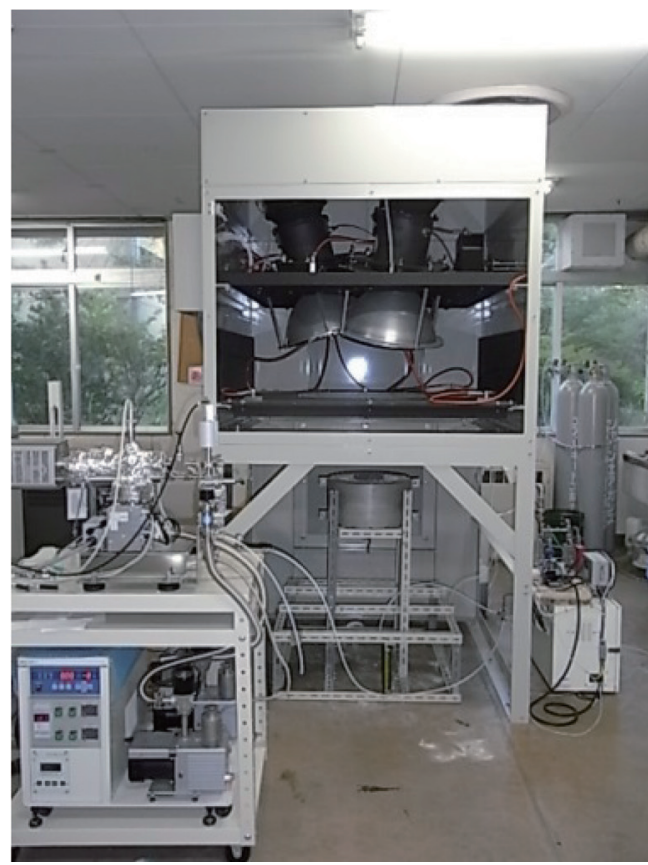

Fig. $65 \mathrm{kWth}$ solar simulator

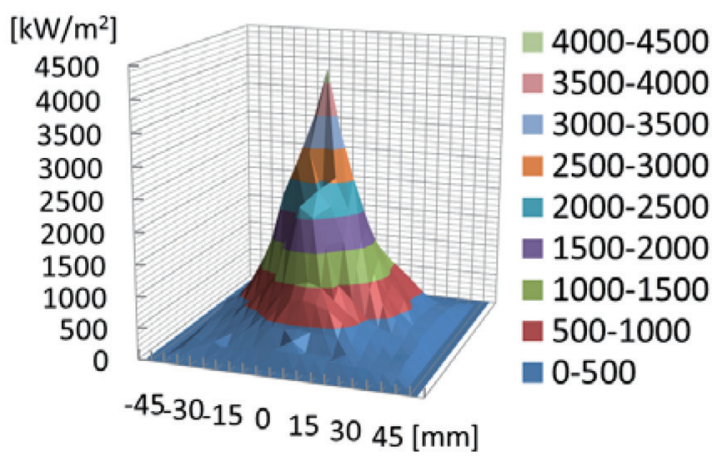

Fig. 7 The distribution of the heat flux for $5 \mathrm{kWth}$

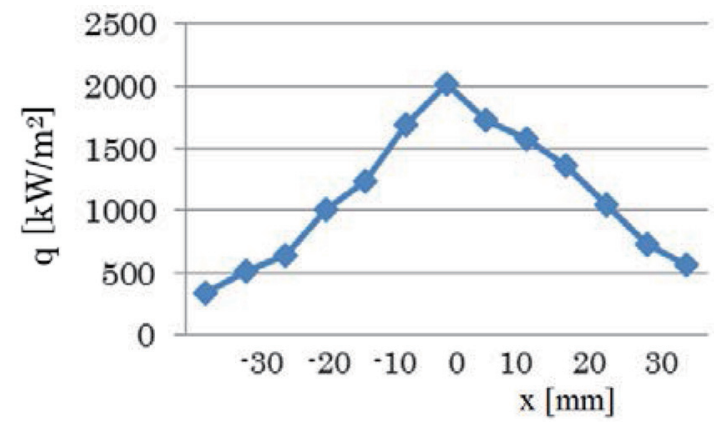

Fig. 8 The distribution of the heat flux

suitable for real situations.

The numerical simulation employed the granular approach for the solid and fluid flows ${ }^{5)}$ 6). This numerical simulation treats the particles as a continuous media. The interaction between the solid particles and the fluid flows are considered by the empirical law. The numerical simulation was made by ANSYS Fluent. The grid mesh was made by surface CAD system of ICEM module. The structured mesh was generated to reduce the computational time. Fig. 9 shows the initial volume fraction of the particles. The particles fill the two towers to the highest level.

Fig. 10 shows particle volume fraction, particle velocity vectors and air velocity vectors after 3.0 seconds from the aeration. Fig. 10 (a) indicates that bubbles are

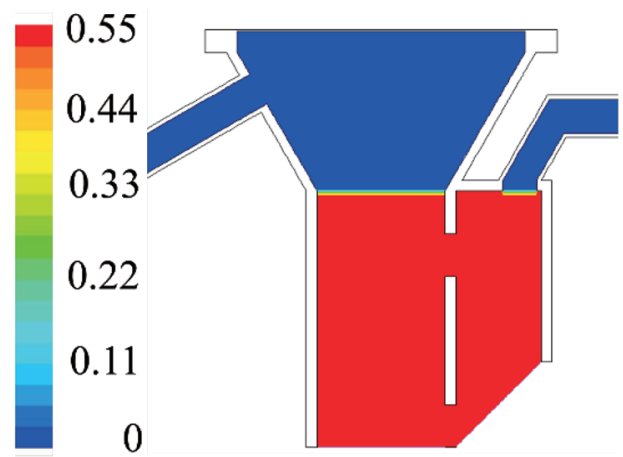

Fig. 9 Particle volume fraction as initial condition 
produced to ascend in the particle bed. The bubbles appear at the corner of the angled distributor and are concentrated along the wall of the low pressure tower. Therefore, the distributor corner tends to deviate the particle flow.

In Fig. 10 (c), air stream goes upward both in highand low-pressure towers. A region of high air velocity appears at the edge of the distributor, overlapping the area with a concentration of bubbles. In Fig. 10 (b), particle streams differs from air flow according to the gravitational
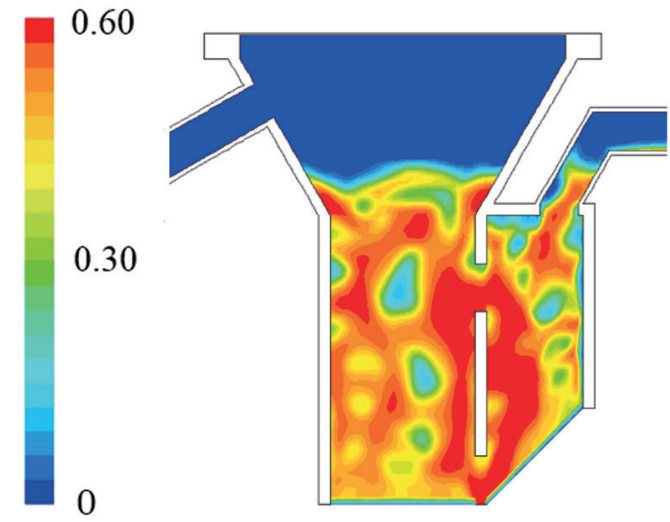

(a) Volume fraction of solid
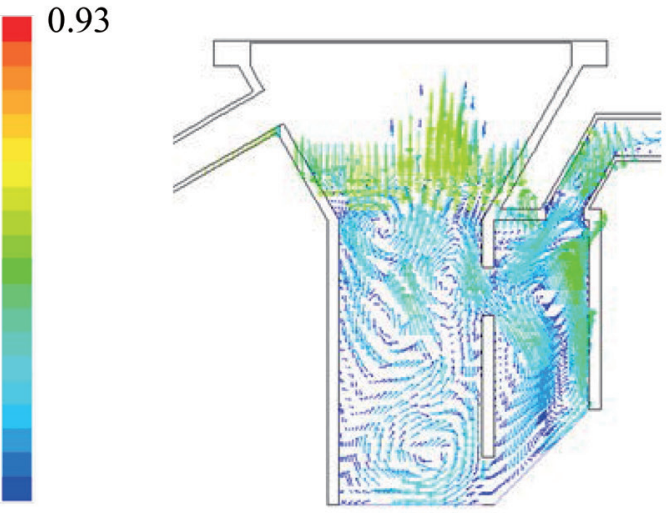

(b) Particle velocity vectors $(\mathrm{m} / \mathrm{s})$

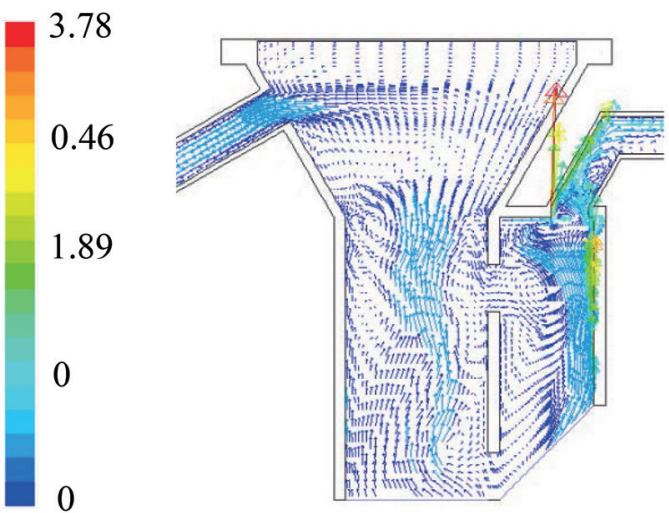

(c) Gas velocity vectors $(\mathrm{m} / \mathrm{s})$

Fig. 10 Distribution after 3 seconds falling. There are local circulations of particle flow in each of the two towers. The circulation in the low pressure tower is clearly visible. This circulation comes from the air flow deviation originated in the angled distributor. The particle mixing seems to contribute in improving the receiver performance through the thermal mixing of the particle bed. This is recommended to be elaborated by adjusting the inclination of the distributor.

Time mean of computed variables are calculated over
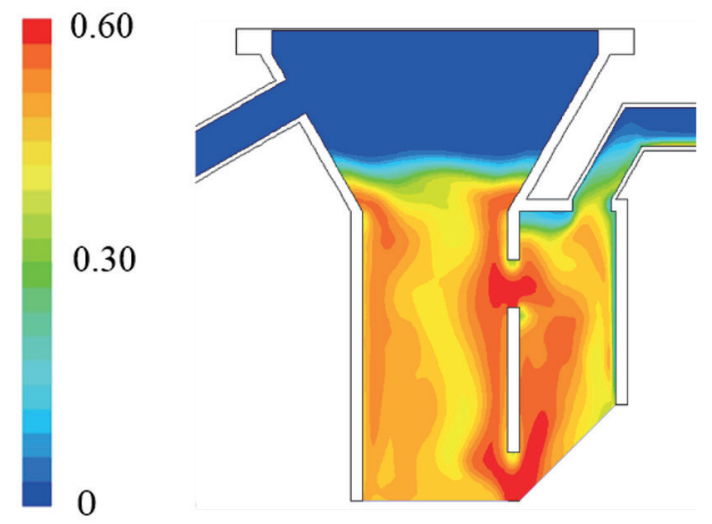

(a) Volume fraction of solid

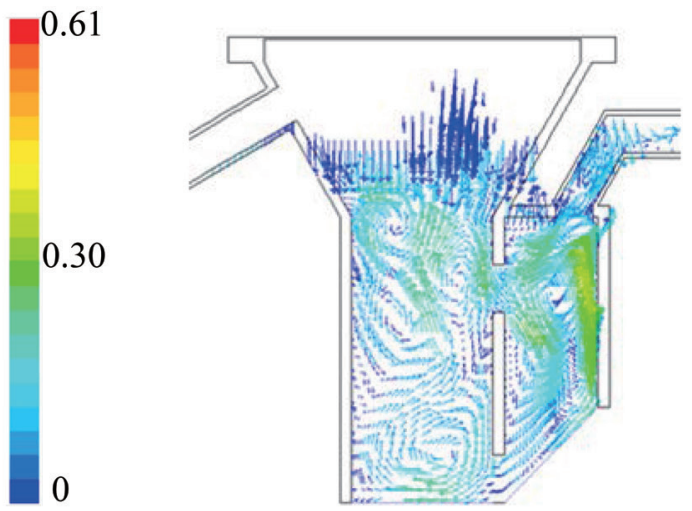

(b) Particle velocity vectors $(\mathrm{m} / \mathrm{s})$
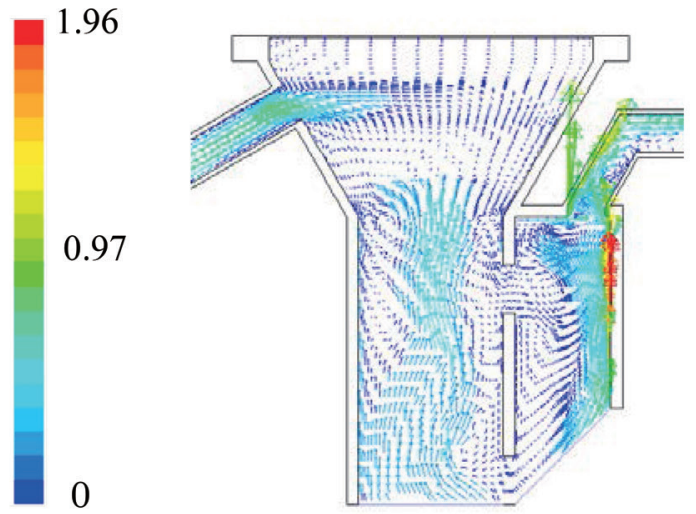

(c) Gas velocity vectors $(\mathrm{m} / \mathrm{s})$

Fig. 11 Mean distribution during 3 seconds 


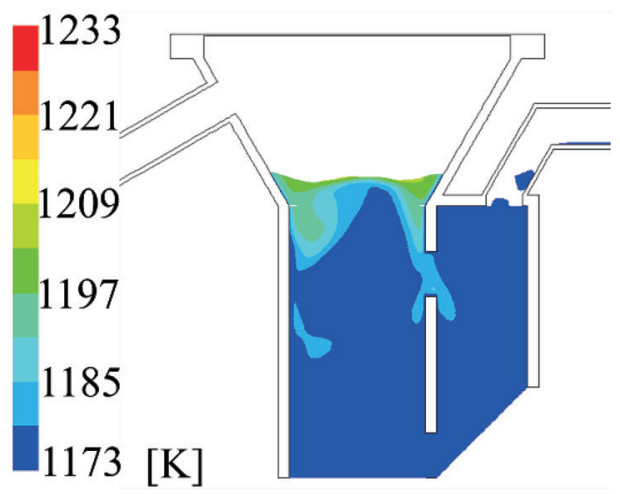

(a) $\mathrm{t}=3[\mathrm{sec}]$

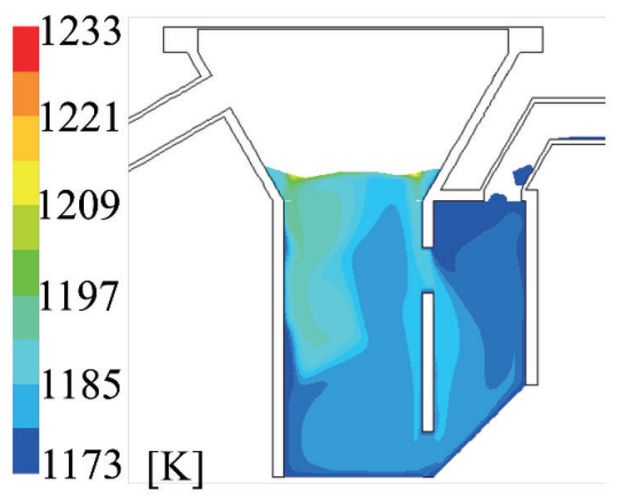

(b) $\mathrm{t}=10[\mathrm{sec}]$

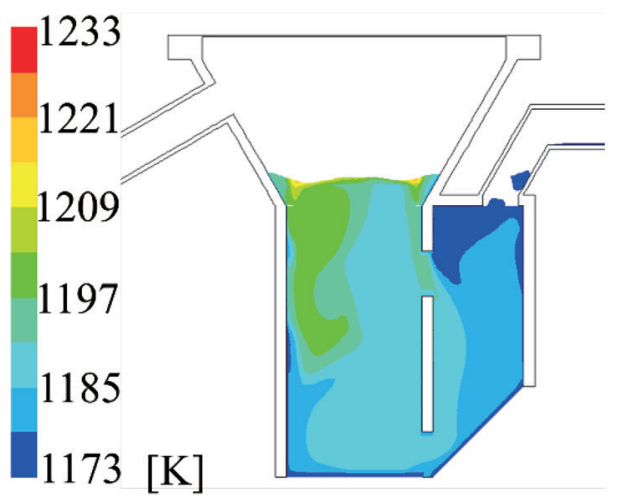

(c) $\mathrm{t}=30[\mathrm{sec}]$

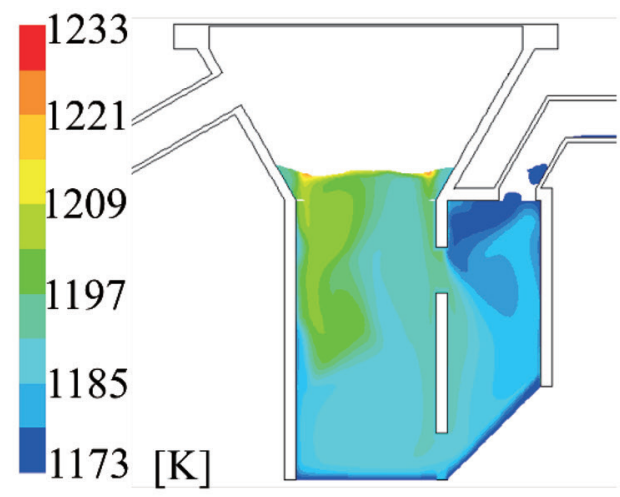

(d) $\mathrm{t}=60[\mathrm{sec}]$

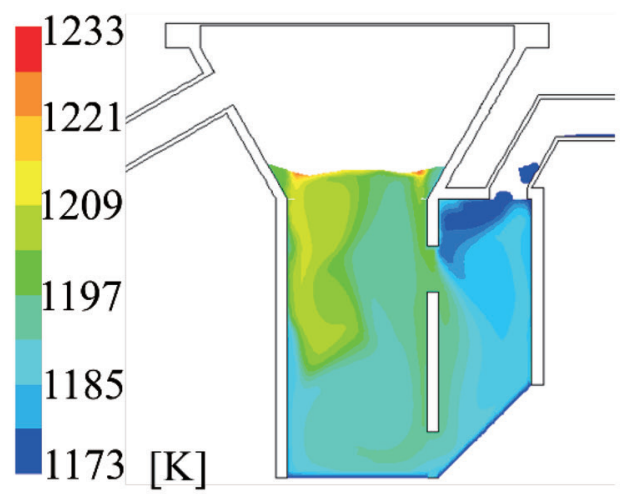

(e) $\mathrm{t}=120[\mathrm{sec}]$

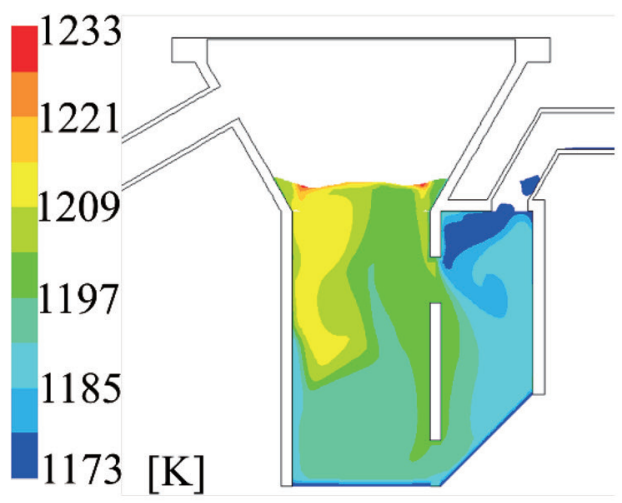

(f) $\mathrm{t}=180[\mathrm{sec}]$

Fig. 12 Temperature distribution during 3 minutes

three seconds after aeration start. Time mean of particle volume fraction, particle velocity vectors and air velocity vectors are presented in Fig. 11.

In Fig. 11 (a), time mean of particle volume fraction is smoother than its instantaneous counterpart. There are thinner distribution of solid particles in the center of high pressure tower and along the side wall of low pressure tower. In Fig. 11 (c), air stream shows weak circulation and mostly ascends throughout two towers. In Fig. 11 (b), particle stream shows strong local circulation in two towers.
The time mean fields are consistent with instantaneous fields. The distinctive characteristics argued for the instantaneous field can be observed more clearly in the time mean field.

Whereas the flow field showed the suggestive changes during three seconds from the aeration, temperature increase was very little during this time interval. The time computation was thus needed to proceed by longer CPU time. Since the computation of the fluid dynamics needs huge CPU time, two weeks or longer, 
only temperature is simulated using the mean flow field during three seconds from aeration start. The computation of temperature during three minutes can be achieved accordingly.

Fig. 12 shows the time history of temperature distribution. The temperature of the high pressure side becomes higher than $950^{\circ} \mathrm{C}$ from the aeration start. The temperature increase reaches the bottom of the particle bed. The thermal penetration in the particle bed is considered to be assisted by the local circulation of particles. It is observed that the temperature increase penetrates into the low pressure side. This suggests the global circulation of particles between high- and low- pressure side towers.

The thermal penetration to the low-pressure side tower suggests that the two-tower type fluidized bed can be employed for the direct heat storage system through particle transport.

\section{Conclusion}

This report examines the flow and temperature in the two-tower type fluidized bed air receiver for highly concentrated solar radiation of solar power generation. The conclusions thus obtained can be summarized as follow:

(1) The experimental visualization of the cold model suggested that the particles are mixed by the organized flow in each tower by aeration.

(2) The numerical simulation model was developed using the granular approach. This can successfully reproduce the fluidization of the particle bed.

(3) The numerical simulation of the two-tower fluidized receiver was made with the thermal input from the $5.0 \mathrm{kWth}$ sun simulator. The numerical simulation demonstrated that the temperature in the high pressure side exceeds $950{ }^{\circ} \mathrm{C}$ after 3.0 minutes from the aeration start.

(4) This paper presents instantaneous field and time mean field of particle volume fraction, particle velocity vectors and air velocity vectors. The quantitative features are commonly observed in both fields. Time mean fields are suitable for clear observation of flow and thermal characteristics since randomness is canceled by unconditional sampling.

The numerical simulation revealed that the heated particles in the high pressure tower penetrates into the low pressure tower. This appears to come from the particle circulation between two towers. This penetration suggested the possibility that the two-tower fluidized bed can be extensively utilized for a direct heat storage system.

\section{References}

1) SOLGATE Solar Hybrid Gas Turbine Electric Power System, Contract ENK5-CT-2000-00333, Final Publishable Report, 2005

2) Fend, T.; Pitz-Paal, R.; Reutter, O.; Bauer, J.; Hoffschmidt, B., Solar Energy Materials \& Solar Cells, 84, 291-304 (2004)

3) Kodama, T.; Gokon, N., Chemical Reviews, 107, 40484077 (2007)

4) Gokon, N.; Yamamoto, H.; Kondo, N.; Kodama, T., ASME J. Solar Engineering, 132, 021102 (10 Pages), (2010)

5) Gidaspow, D.; Jiradilok, V., Computational Techniques: The Multiphase CFD Approach to Fluidization, and Green Energy Technologies, Nova Science Pub Inc., (2010)

6) Matsubara, K.; Kazuma, Y.; Sakurai, A.; Suzuki, S.; Soon-Jae, L.; Kodama, T.; Gokon, N.; Hyun Seok, C.; Yoshida, K., Energy Procedia, 49, 447-456 (2014) 